\title{
Kaji teoritis EMS (Engine Management System) dengan variasi temperatur air pendingin dan beban kerja pada kondisi stasioner pada kendaraan Toyota Avanza
}

\author{
Angga Wahyu Prama yudha1 ${ }^{1}$, Gunarko²$^{2}$, Ardyanto Darmanto ${ }^{*}$, F.A. Widiharsa ${ }^{4}$ \\ Prodi Teknik Otoranpur Politeknik Angkatan Darat \\ Kesatrian Pusdik Arhanud Pussenarh, Kodiklat TNI AD, Desa Pendem Kecamatan \\ Junrejo, Kota Batu, Malang, Jawa Timur \\ *Corresponding author: ardyantodarmanto123@yahoo.com
}

\begin{abstract}
EMS is a control system on the engine to regulate the proper mixing of air and fuel, accurate ignition timing, and control of other systems on the engine, according to the conditions and workload of the vehicle. The EMS component consists of sensors, ECU, and actuator. Engine control is fully regulated by the ECU. After getting data from the sensor, the ECU sensor will signal the actuator to control the engine, so that the work of the engine can be controlled according to the conditions of the engine. The effect of the cooling water temperature sensor is very large at stationary (Idle Speed Control/ISC). This research method is carried out by varying the temperature of cooling water (Engine Coolant Temperature/ECT) to get the mass of gasoline, air mass, air fuel ratio, engine speed, ignition angle, and gasoline consumption at each ISC load. The results of the research and data processing show that gasoline consumption will decrease every time the cooling water temperature increases. The $A C$ (Air Conditioner) load ranges from $1,123 \times 10^{-2}$ to $2,164 \times 10^{-2} \mathrm{~kg} /$ hour, the power steering load ranges from 6,311 $\times 10-3$ to 9,482 $\times 10-3 \mathrm{~kg} / \mathrm{hour}$, the electrical load ranges from $6,608 \times$ $10^{-3}$ to $7,876 \times 10^{-3} \mathrm{~kg} / \mathrm{hour}$ and without load ranges from $6,024 \times 10^{-3}$ to $7,920 \times 10^{-3} \mathrm{~kg} / \mathrm{hour}$. From these data it can be concluded that the effect of the ECT sensor is very large on engine performance at stationary rotation (ISC).
\end{abstract}

Keywords: Sensor, ECU, Actuator.

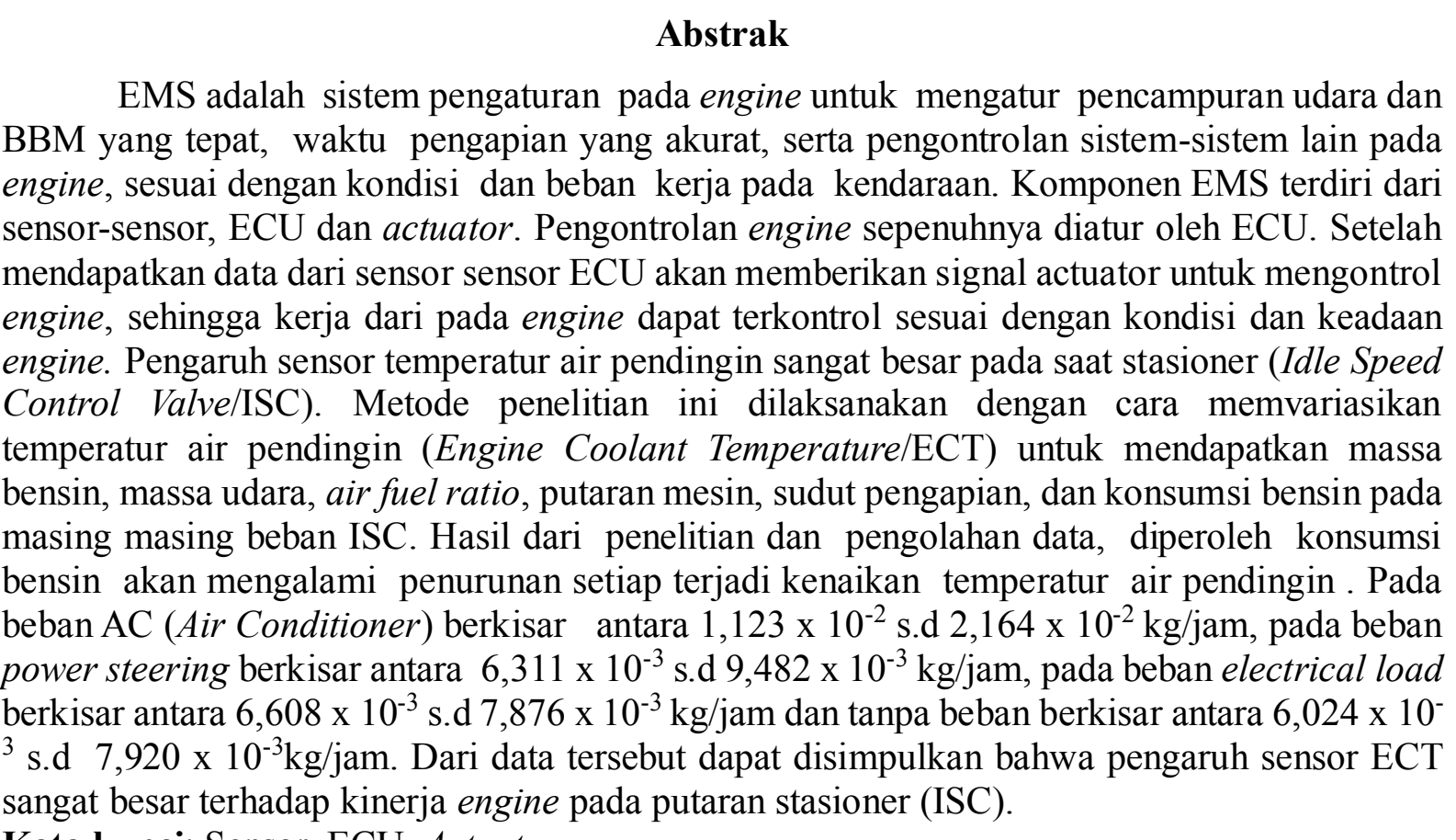

Kata kunci: Sensor, ECU, Actuator. 


\section{Pendahuluan}

Kemajuan teknologi kendaraan dan emisi gas buang sesuai dengan EURO (European Emission Standart) 3, mewajibkan produsen kendaraan memiliki emisi gas buang yang ramah lingkungan. Sehingga diciptakan rekayasa sistem pemasukan bahan bakar dan udara yang mudah dikontrol dan presisi, sesuai dengan kondisi dan keadaan beban mesin. Teknologi ini dinamakan EMS (Engine management system), dikontrol sepenuhnya oleh ECU (Electronic control unit), untuk mengatur perbandingan bahan bakar dan udara bakar yang tepat, waktu pengapian yang akurat, serta pengontrolan sistemsistem lain pada engine, sesuai dengan kondisi dan beban kerja kendaraan. Dengan pengontrolan EMS konsumsi penggunaan BBM yang lebih hemat dan performa engine yang meningkat. Kemajuan teknologi tersebut tidak diikuti oleh kemampuan SDM, Kesalahan dalam hal pemeliharaan dan perbaikan kendaraan yang telah menggunakan EMS masih terjadi [1].

Engine yang menggunakan EMS terdiri dari beberapa sistem diantaranya adalah ISC (Idle speed control) berfungsi sebagai sistem yang mengatur jumlah udara masuk ketika throttle valve position tertutup dan engine pada posisi putaran stationer. ISC dipasang secara by pass terhadap katup throttle valve engine, jumlah volume udara yang masuk kedalam ruang bakar diatur sepenuhnya oleh ECU, persentase (\%) pembukaan katup ISC sangat tergantung pada temperatur air pendingin engine, dan beban-beban pada stasioner (ISC) kendaraan [2].

\section{Kajian Pustaka}

\section{EMS (Engine management system)}

Engine Manajement System adalah suatu sistem pengaturan pada engine yang mengatur dan mengontrol seluruh sistem pada engine, dikendalikan oleh Electronic Control Unit (ECU), sehingga performance engine terkontrol sesuai dengan kondisi dan keadaan terbaik. Komponen EMS terdiri dari sensor-sensor sebagai data input, ECU, dan actuator. Signal input diproses di ECU kemudian ECU akan mengeluarkan output berupa tegangan (volt) dan dikirim ke setiap actuator di seluruh sistem-sistem yang ada pada engine [3].

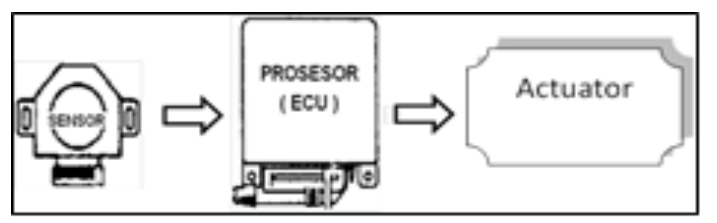

Gambar 1.Pengolahan signal pada EMS

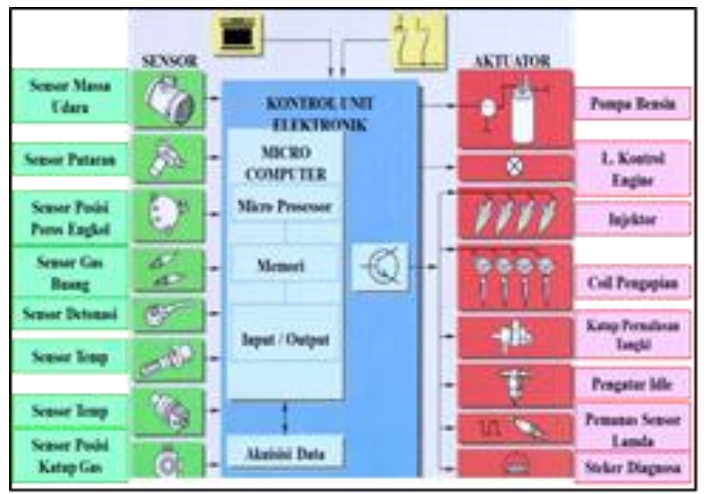

Gambar 2. Diagram Engine Manajement System

\section{ISC (Idle Speed Control)}

Idle Speed Control merupakan salah satu jenis actuator pada EMS yang berfungsi sebagai pengatur udara masuk ke intake manifold ketika throttle valve position dalam keadaan tertutup dan engine pada posisi putaran stasioner. ISC dipasang secara by pass terhadap katup throttle valve engine, banyaknya udara yang masuk kedalam ruang bakar diatur sepenuhnya oleh ECU [4].

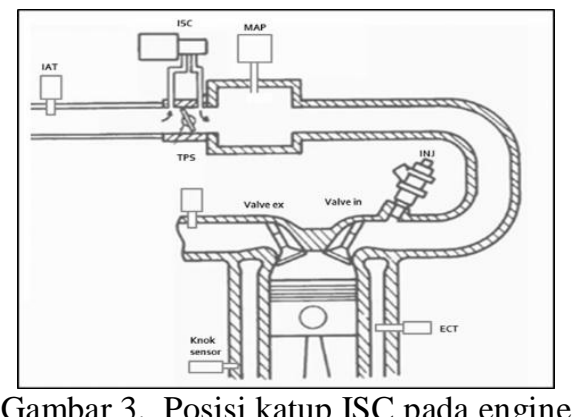

Gambar 3. Posisi katup ISC pada engine

\section{Sensor ECT (Engine coolant Temperature)}

Sensor ECT berfungsi mengirim signal tegangan berupa informasi kepada ECU tentang temperatur cairan pendingin 
(engine coolant) pada engine. Bahan sensor ECT terdiri dari Solid-state variable resistor semiconductor NTC (Negative Temperature Coefficient) [5]. NTC adalah Thermistor yang nilai tahananya berkurang bila temperatur naik (nilai tahanan berbanding terbalik terhadap temperatur).

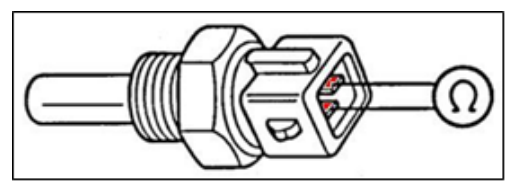

Gambar 4. Sensor ECT

\section{Sensor IAT (Intake Air Temperature)}

Sensor IAT adalah sensor pada EMS yang mendeteksi temperatur udara masuk kedalam intake manifold. Prinsip kerja dan rangkaian electronic sensor ini sama dengan sensor ECT dimana tegangan signal dan tahanan IAT akan berubah ketika terjadi perubahan temperature [6].

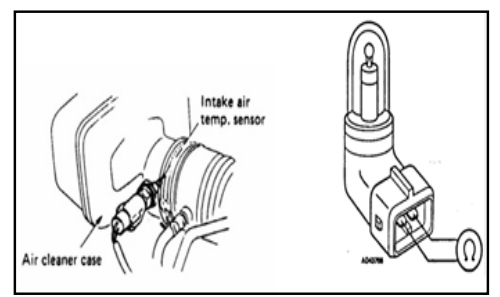

Gambar 5. Sensor IAT

\section{Sensor MAP (Manifold Absolute Pressure)}

Sensor MAP adalah jenis sensor yang dapat mengindikasikan tekanan udara pada intake manifold dan dikonversikan menjadi kecepatan udara pada intake manifold. Sensor ini bekerja dengan prinsip perbedaan tekanan (kevakuman) pada intake manifold dengan ruang vakum pada sensor. Membran terbuat dari bahan Piezo Resistive dimana tahanan sensor ini akan berubah ketika terjadi perubahan bentuk pada membran akibat dari tekanan vakum pada intake manifold [7].

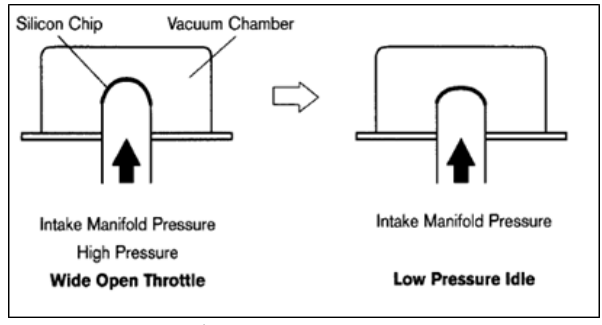

Gambar 6. Sensor MAP

\section{Switch AC (Air Conditioner)}

Ketika engine idle dan Switch $A C$ dihidupkan maka engine akan menerima beban tambahan berupa kompressor AC, ECU akan memerintahkan ISC membuka lebih lebar dan injector akan menyemprotkan bahan bakar lebih banyak. Sehingga engine tidak mati ketika menerima baban lebih besar. Pengaruh switch AC sangat dominan dalam kerja ISC.

\section{Sensor electronic power steering}

Pada saar engine berputar idle dan power stering digerakkan, maka hydraulic pump pada power steering akan membutuhkan tekanan oil yang besar sehingga akan menambah beban kerja pada engine, dan daya yang lebih agar engine tidak mati. Pada saat control valve terbuka maka secara otomatis sensor tekanan oil hydraulic akan mengirim signal ke ECU, ECU akan memerintahkan ISC untuk membuka lebih besar untuk menaikkan putaran engine.

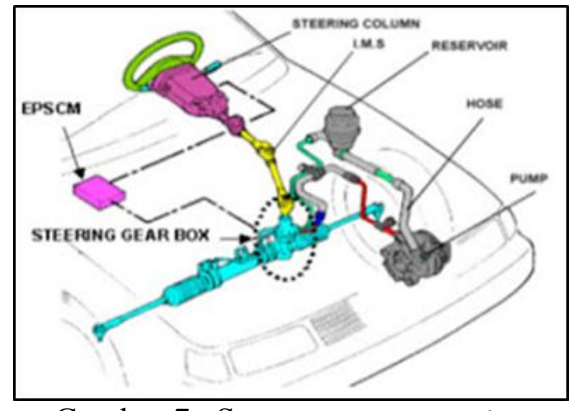

Gambar 7. Sensor power steering

\section{Sensor electrical load}

Sensor electrical load adalah sensor yang berfungsi untuk mendeteksi penggunaan listrik. Ketika terjadi penggunaan daya listrik yang besar (head lamp, blower $A C$ ), maka sensor akan mengirim signal ke ECU dan ECU akan menambah tegangan yang masuk kedalam rotor di alternator, kemagnetan pada alternator akan bertambah dan akan menghasilkan tegangan listrik yang sesuai dengan kebutuhan beban. Pada saat bersamaan ECU juga akan memerintahkan ISC untuk membuka katup lebih besar sehingga RPM akan naik. Karena engine membutuhkan daya yang lebih untuk memutar alternator [8]. 


\section{EFI (Electronic Fuel Injection)}

EFI (Elektronik fuel Injektion) adalah sebuah sistem penyemprotan bahan bakar secara elektronik, untuk mendapatkan nilai campuran udara dan bahan bakar selalu sesuai dengan kebutuhan engine, sehingga didapatkan daya motor yang optimal. Dengan pemakaian bahan bakar yang tepat akan menghasilkan gas buang yang ramah lingkungan [9].

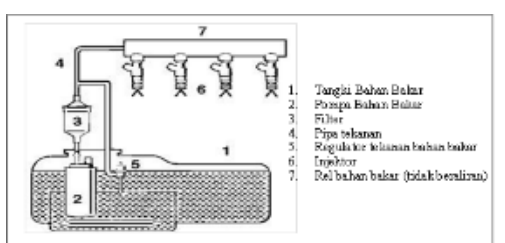

Gambar 8. Sistem aliran bahan bakar EFI

Pembukaan katup injector terjadi ketika lilitan kabel dialiri tegangan listrik dari ECU, sehingga terjadi electromagnetic pada lilitan tersebut dan akan membuka lubang penyemprot pada injector. Ketika tegangan listrik hilang, maka kemagnetan pada kumparan akan hilang sehingga lubang penyemprotan akan tertutup oleh pegas pengembali. Banyaknya bahan bakar yang disemprotkan tergantung dari lamanya pembukaan katup injector tergantung oleh tegangan yang diberikan oleh ECU.

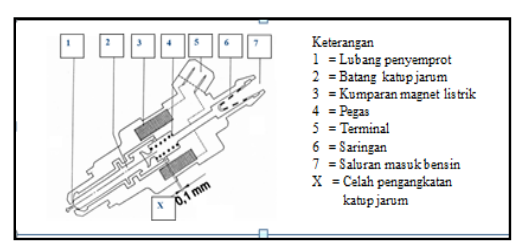

Gambar 9. Konstruksi injector pada EFI

\section{Sistem pemasukan udara (Intake Air System)}

Sistem pemasukan udara pada motor bakar bensin terjadi pada langkah isap (intake stroke) ketika piston bergerak dari TDC (Top Death Centre) menuju BDC (Bottom Death Centre) dan katup hisap (intake valve) terbuka, volume silinder membesar mengakibatkan kevakuman dalam silinder dan udara akan masuk ke dalam silinder. Pada saat putaran mesin stationer (idle), udara akan masuk melalu filter udara (air filter) kemudian melewati katup ISC [10].

\section{Waktu pembukaan katup}

Waktu pembukaan katup dipengaruhi oleh konstruksi camshaft. Pada umumnya besar sudut pembukaan katup hisap dan katup buang adalah $230^{\circ}$ sampai $270^{\circ}$.

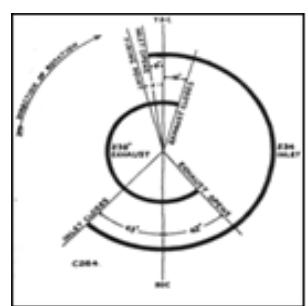

Gambar 10. Pembukaan katup pada camshaft

\section{AFR (Air Fuel Ratio)}

AFR (Air Fuel Ratio) adalah perbandingan massa udara dan bahan bakar. Secara teoritis campuran udara dan bahan bakar yang sempurna adalah campuran bahan bakar yang menghasilkan gas buang $\mathrm{CO}_{2}$ dan $\mathrm{H}_{2} \mathrm{O}$.

\section{Metode Penelitian}

\section{Diagram alir penelitian}

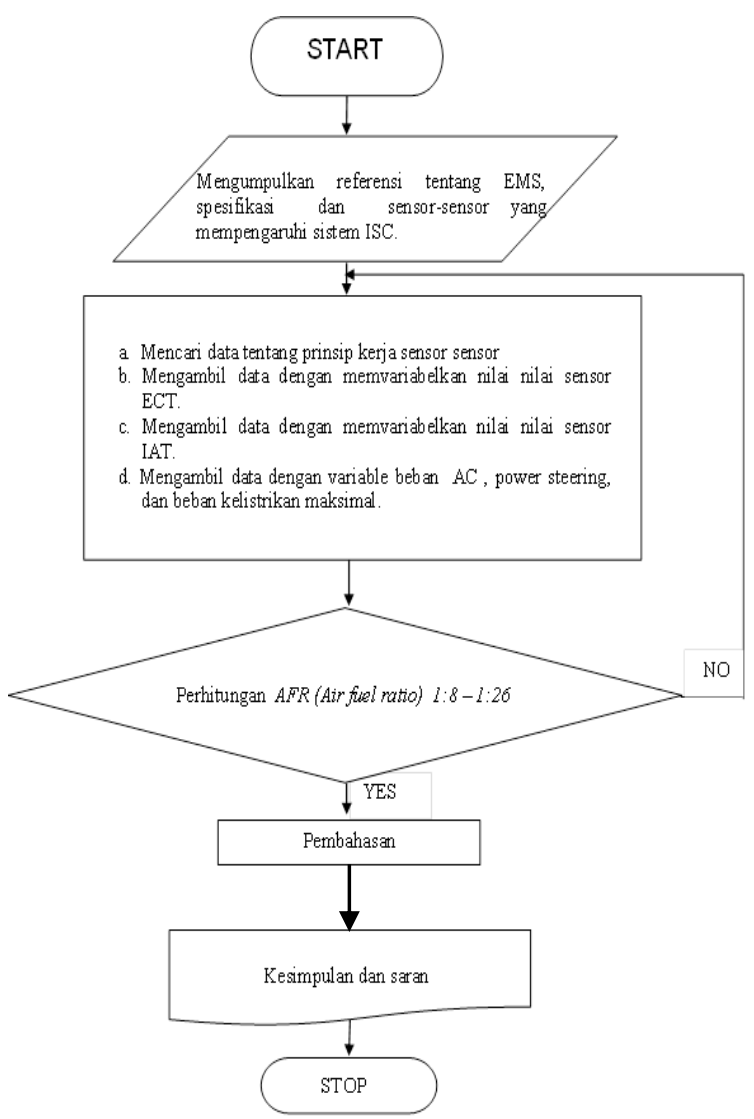

Gambar 11. Diagram alir penelitian 


\section{Variabel bebas}

Variabel bebas pada penelitian ini adalah sensor ECT, sensor IAT, beban AC, beban power steering,beban electrical load, tanpa beban.

\section{Variabel terikat}

Variabel terikat pada penelitian ini adalah: massa bensin, massa udara, AFR, waktu pengapian, putaran mesin (rpm) dan konsumsi bensin.

\section{Alat dan bahan dalam pengambilan data}

Terdiri dari: Kendaraan Toyota Avanza, Scan tool, DLC, OBD, tool kit, avometer, solder listrik, simulasi sensor ECT dan IAT.

\section{Prosedur pengambilan data}

Menghidupkan engine dan memastikan tidak ada throble code pada scan tool. Memposisikan simulasi sensor IAT $\left(10^{\circ} \mathrm{C}\right.$ s.d $\left.40^{\circ} \mathrm{C}\right)$ dan simulasi sensor $\left(20^{\circ} \mathrm{C}\right.$ s.d $\left.100^{\circ} \mathrm{C}\right)$. Mencatat dan merekam/photo data yang ada pada scan tool pada keadaan tanpa beban (TB), Power steering (PS), electrical load (EL), dan AC.

\section{Hasil dan Pembahasan}

1. Bahan bakar (premium)

a. Debit bahan bakar pada injector

$$
\begin{aligned}
& Q=\frac{\text { Volume rata }- \text { rata }\left(\mathrm{cm}^{3}\right)}{t(\mathrm{~s})} \\
& Q=3,5 \mathrm{~cm}^{3} / \mathrm{s}=0,0000035 \mathrm{~m}^{3} / \mathrm{s}
\end{aligned}
$$

b. Laju aliran massa $(\mathrm{kg} / \mathrm{s})$

$$
\begin{aligned}
& \dot{\mathrm{m}}=\rho\left(\mathrm{kg} / \mathrm{m}^{3}\right) \times \mathrm{Q}\left(\mathrm{m}^{3} / \mathrm{s}\right) \\
& \dot{\mathrm{m}}=0,002519(\mathrm{~kg} / \mathrm{s})
\end{aligned}
$$

c. Massa Bensin $(\mathrm{kg})$

$$
\begin{aligned}
& \mathrm{m}=\dot{\mathrm{m}}(\mathrm{kg} / \mathrm{s}) \times \mathrm{t}_{\text {inj }}(\mathrm{s}) \\
& \mathrm{m}=5,0379 \times 10^{-6} \mathrm{~kg}
\end{aligned}
$$

\section{Udara}

a. Waktu pembukaan intake valve (s)

$$
\begin{aligned}
& t_{v}=\frac{60}{n} \times\left(\frac{\alpha_{v}}{360}\right) \\
& t_{v}=0,0246523(\mathrm{~s})
\end{aligned}
$$

b. Densitas udara $\left(\mathrm{kg} / \mathrm{m}^{3}\right)$

$$
\begin{aligned}
& \rho=\frac{P(P a)}{R(\mathrm{~J} / \mathrm{kg} \cdot \mathrm{K}) \times T(K)} \\
& \rho=0,311696\left(\mathrm{~kg} / \mathrm{m}^{3}\right)
\end{aligned}
$$

c. Kecepatan aliran udara pada intake manifold

$$
\begin{aligned}
& v=\sqrt{\frac{2 \cdot\left(P_{1}-P_{2}\right)\left(\mathrm{N} / \mathrm{m}^{2}\right)}{\rho\left(\mathrm{kg} / \mathrm{m}^{3}\right)}} \\
& v=659,088 \mathrm{~m} / \mathrm{s}
\end{aligned}
$$

d. Luas penampang pembukaan katup ISC

$$
\begin{aligned}
& A_{I S C}=A_{b y} \text { pass } \\
& A_{I S C} \\
& =1,2083 \times 10^{-5}\left(\mathrm{~m}^{2}\right)
\end{aligned}
$$

e. Debit udara pada intake manifold

$$
\begin{aligned}
& Q_{\text {udara }}=V(\mathrm{~m} / \mathrm{s}) \times A_{\text {isc }}\left(\mathrm{m}^{2}\right) \\
& Q_{\text {udara }}=0,0080 \mathrm{~m}^{3} / \mathrm{s}
\end{aligned}
$$

f. Laju aliran massa udara

$$
\begin{aligned}
& \dot{m}=\rho\left(\mathrm{kg} / \mathrm{m}^{3}\right) \times Q\left(\mathrm{~m}^{3} / \mathrm{s}\right) \\
& \dot{m}=0,002482367(\mathrm{~kg} / \mathrm{s})
\end{aligned}
$$

g. Massa udara $(\mathrm{kg})$

$$
\begin{aligned}
& \mathrm{m}=\dot{\mathrm{m}} \cdot{ }^{t_{v}} \\
& \mathrm{~m}=0,000196333(\mathrm{~kg})
\end{aligned}
$$

3. AFR (air fuel ratio)

AFR = massa udara $(\mathrm{kg})$ : massa bensin $(\mathrm{kg})$ $\mathrm{AFR}=12,14715648 \quad: 1$

4. Konsumsi bahan bakar bensin (kg/jam)

$$
\begin{aligned}
& K=\frac{n \times m_{b b m}}{2} \times 60 \times z \\
& K=0,956394936(\mathrm{~kg} / \mathrm{jam})
\end{aligned}
$$

5. Hubungan ECT dengan bensin (kg)

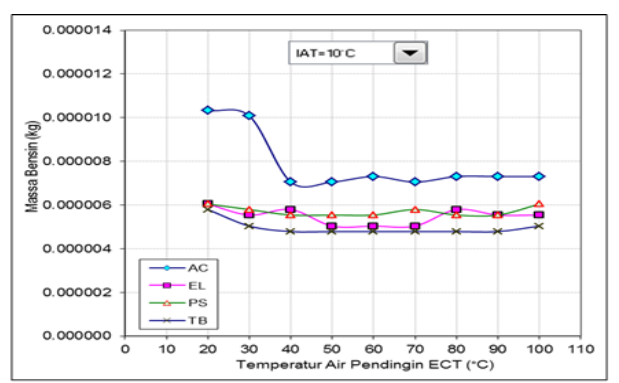

Gambar 12. Grafik hubungan antara ECT dengan massa bensin pada temperatur udara $10^{\circ} \mathrm{C}$

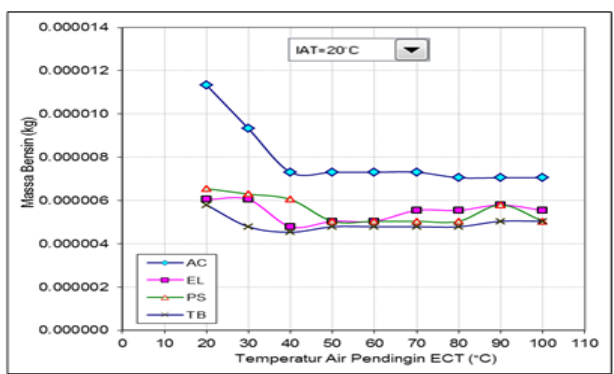

Gambar 13. Grafik hubungan antara ECT dengan massa bensin pada temperatur udara $20^{\circ} \mathrm{C}$ 


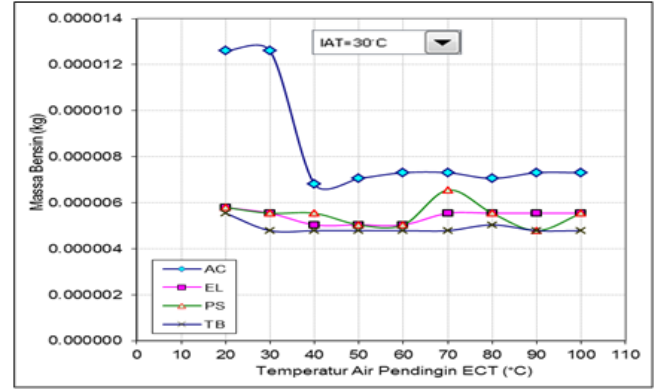

Gambar 14. Grafik hubungan antara ECT dengan massa bensin pada temperatur udara $30^{\circ} \mathrm{C}$

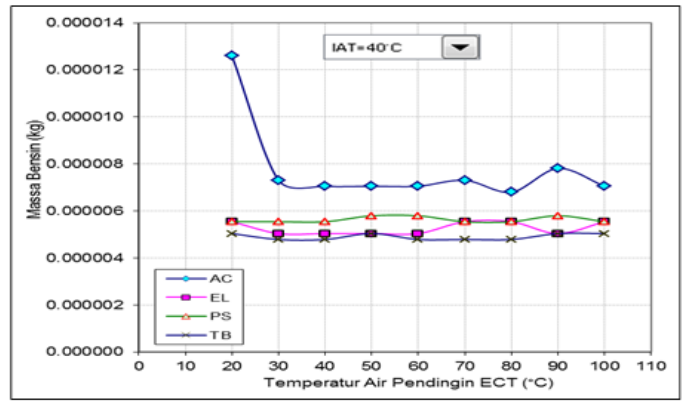

Gambar 15. Grafik hubungan antara ECT dengan massa bensin pada temperatur udara $40^{\circ} \mathrm{C}$

Dari Gambar 12, 13, 14 dan 15 disimpulkan pengaruh temperatur air pendingin terhadap massa bensin yang paling besar terdapat pada temperatur $20^{\circ} \mathrm{C}$ $40^{\circ} \mathrm{C}$. Setelah temperatur air pendingin mencapai $50-100^{\circ} \mathrm{C}$ massa bensin relatif konstan. Hal ini karena pada temperatur 20$40^{\circ} \mathrm{C}$ dibutuhkan campuran udara dan bahan bakar (AFR) yang lebih kaya, sehingga memudahkan proses starting engine, mempercepat tercapainya temperatur kerja pada engine, sehingga efisiensi maksimal engine lebih cepat tercapai [5].

Ketika temperatur air pendingin masih rendah $\left(20-40^{\circ} \mathrm{C}\right)$ massa bensin akan mengalami penurunan setiap kenaikan temperatur air pendingin, dengan metode regresi linear, untuk beban $\mathrm{AC}$ berkisar antara $1,637 \times 10^{-7}$ s.d. $2,89610^{-7} \mathrm{~kg}$, beban power steering berkisar antara $1,239 \times 10^{-8}$ s.d. $2,519 \times 10^{-8} \mathrm{~kg}$ pada beban electrical load berkisar antara $1,259 \times 10^{-8}$ s.d. $6,297 \times 10^{-8} \mathrm{~kg}$ dan tanpa beban berkisar antara $1,259 \times 10^{-8}$ s.d. $6,297 \times 10^{-8} \mathrm{~kg}$.
6. Hubungan ECT dengan massa udara

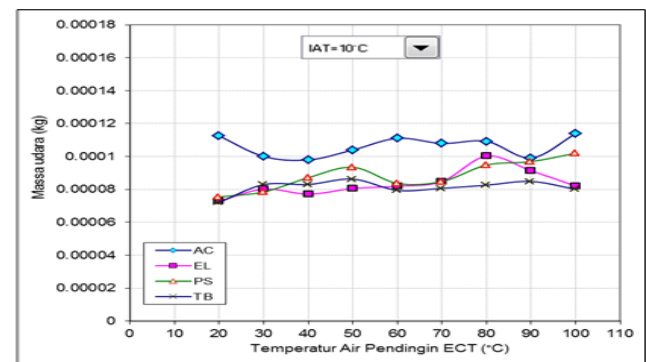

Gambar 16. Grafik hubungan antara ECT dengan massa udara pada temperatur $10^{\circ} \mathrm{C}$

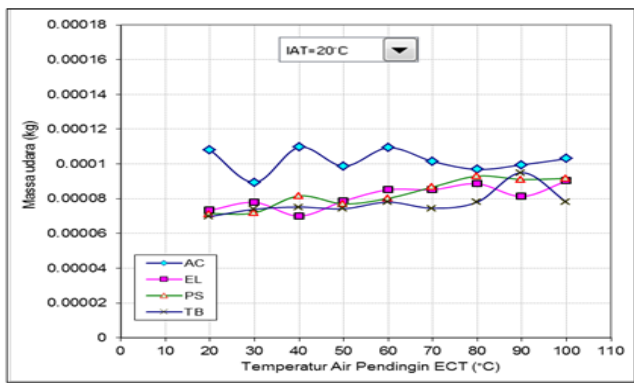

Gambar 17. Grafik hubungan antara ECT dengan massa udara pada temperatur $20^{\circ} \mathrm{C}$

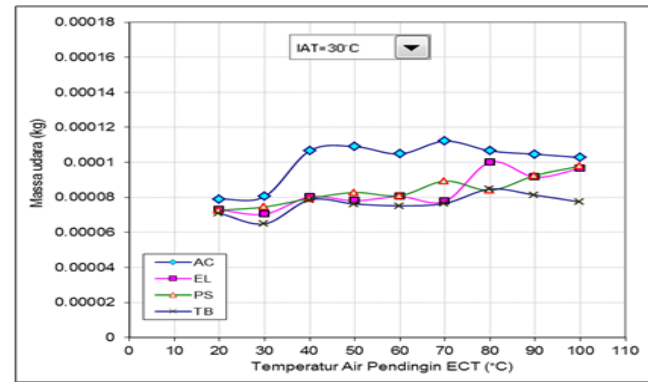

Gambar 18. Grafik hubungan antara ECT dengan massa udara pada temperatur $30^{\circ} \mathrm{C}$

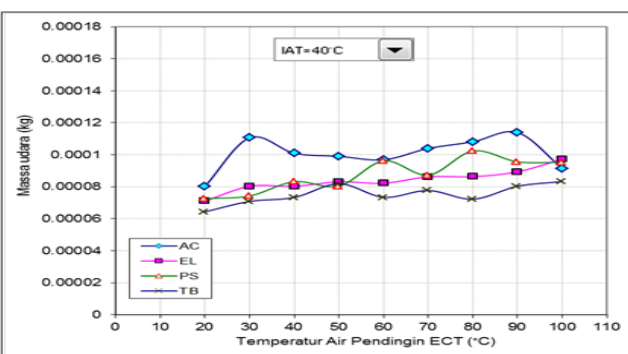

Gambar 19. Grafik hubungan antara ECT dengan massa udara pada temperatur $40^{\circ} \mathrm{C}$

Dari gambar grafik 16, 17, 18, dan 19 diperoleh pengaruh temperatur air pendingin terhadap massa bensin adalah berbanding lurus terhadap kenaikan temperatur air pendingin. Dimana setiap kenaikan temperatur air pendingin akan diikuti dengan kenaikan massa udara. Pada saat temperatur air pendingin rendah dibutuhkan nilai AFR yang kaya untuk 
memudahkan starting engine. ECU akan mengatur pemasukan nilai massa udara yang rendah, sehingga mendapatkan nilai AFR yang kaya. Setelah temperatur air pendingin naik maka secara perlahan massa udara akan dinaikan untuk mencapai AFR yang ideal sehingga mendapatkan kesempurnaan pembakaran dan menghasilkan emisi gas buang yang rendah [5].

Melalui metode regresi linear, setiap kenaikan temperatur air pendingin, akan menaikan massa udara untuk beban AC berkisar antara $4,927 \times 10^{-8}$ s.d. $1,225 \times 10^{-7} \mathrm{~kg}$ beban power steering berkisar antara $2,804 \times 10^{-7}$ s.d. $3,331 \times 10^{-7} \mathrm{~kg}$ pada beban electrical load pada kisaran antara $2,006 \times 10^{-7}$ s.d. $3,29 \times 10^{-7} \mathrm{~kg}$ dan tanpa beban pada kisaran antara $1,461 \times 10^{-8}$ s.d. $5,149 \times 10^{-8} \mathrm{~kg}$.

\section{Hubungan ECT dengan AFR}

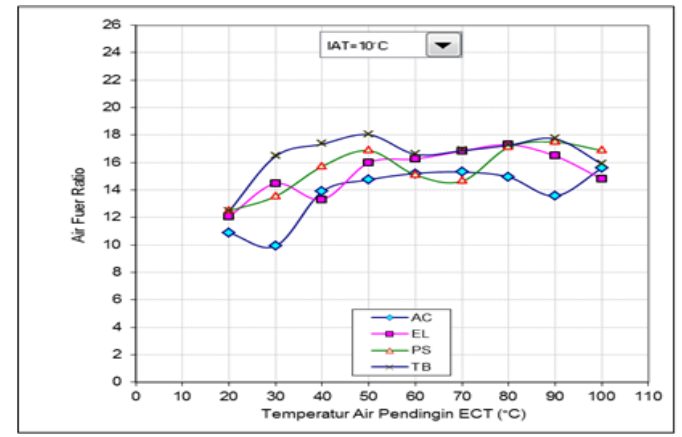

Gambar 20. Grafik hubungan antara ECT dengan AFR pada temperatur $10^{\circ} \mathrm{C}$

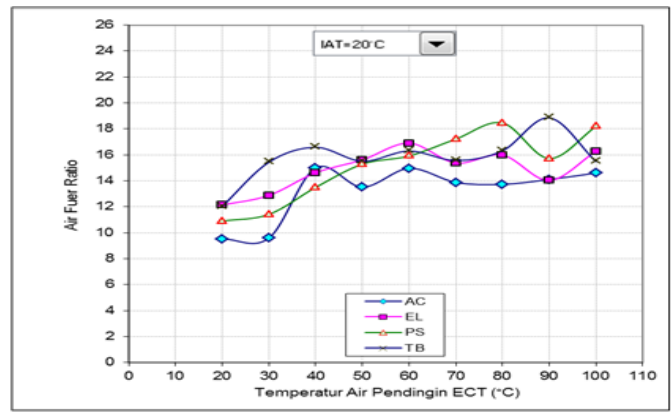

Gambar 21. Grafik hubungan antara ECT dengan AFR pada temperatur $20^{\circ} \mathrm{C}$

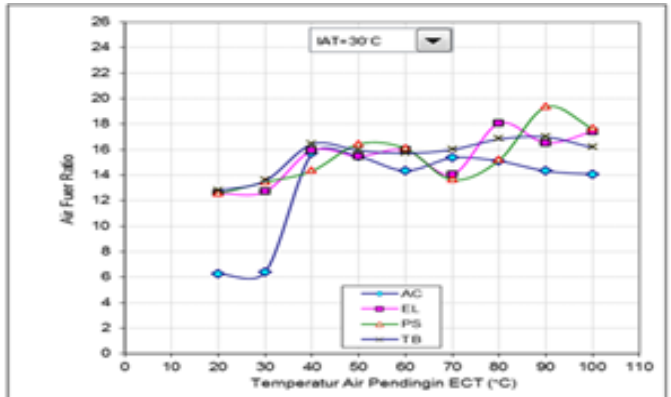

Gambar 22. Grafik hubungan antara ECT dengan AFR pada temperatur $30^{\circ} \mathrm{C}$

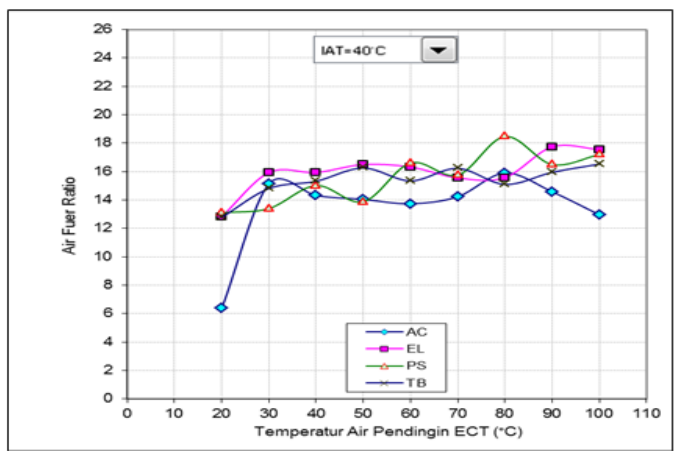

Gambar 23. Grafik hubungan antara ECT dengan AFR pada temperatur $40^{\circ} \mathrm{C}$

Dari gambar grafik 20, 21, 22 dan 23 diperoleh pengaruh temperatur air pendingin terhadap AFR adalah berbanding lurus. Setiap kenaikan temperatur air pendingin akan diikuti dengan kenaikan nilai AFR. Pada temperatur air pendingin masih rendah dibutuhkan nilai AFR yang kaya (5-10:1) untuk memudahkan starting engine. Setelah engine hidup dan temperatur air pendingin naik, nilai AFR akan naik akibat dari pemasukan massa udara yang meningkat. Hal ini akan mengakibatkan pembakaran menjadi sempurna dan akan menghasilkan emisi gas buang yang rendah [5].

Kenaikan nilai AFR terjadi setiap kenaikan temperatur air pendingin. Dengan metode regresi linear, pada beban AC berkisar antara $4,671 \times 10^{-2}$ s.d. $8,954 \times 10^{-2} \mathrm{~kg}$ beban power steering berkisar antara $4,999 \times 10^{-2}$ s.d. $8,989 \times 10^{-2} \mathrm{~kg}$ pada beban electrical load berkisar antara $3,750 \times 10^{-2}$ s.d. $5,602 \times 10^{-2} \mathrm{~kg}$ dan tanpa beban berkisar antara $2,700 \times 10^{-2}$ s.d. $4,103 \times 10^{-2} \mathrm{~kg}$. 
8. Hubungan ECT terhadap putaran mesin (rpm)

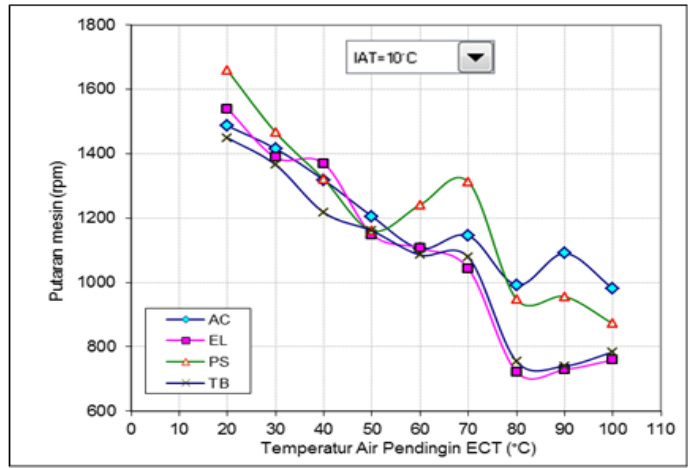

Gambar 24. Grafik hubungan antara ECT dengan putaran mesin pada temperatur $10^{\circ} \mathrm{C}$

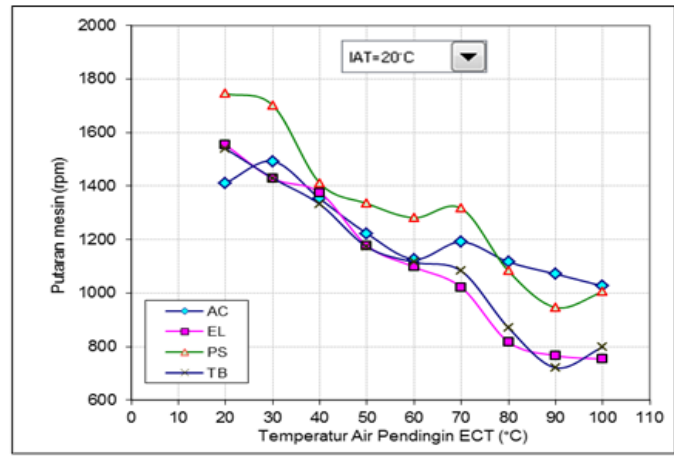

Gambar 25. Grafik hubungan antara ECT dengan putaran mesin pada temperatur $20^{\circ} \mathrm{C}$

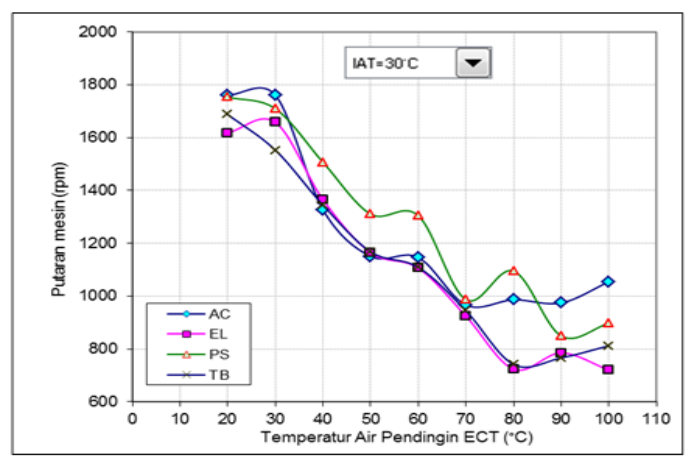

Gambar 26. Grafik hubungan antara ECT dengan putaran mesin pada temperatur $30^{\circ} \mathrm{C}$

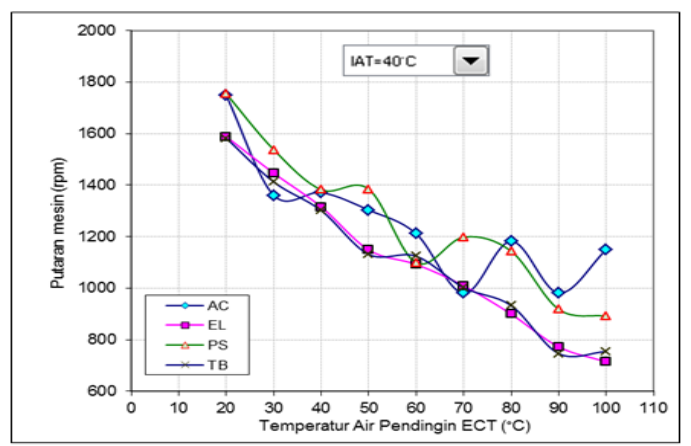

Gambar 27. Grafik hubungan antara ECT dengan putaran mesin pada temperatur $40^{\circ} \mathrm{C}$

Dari gambar grafik 24, 25, 26 dan 27 dapat disimpulkan pengaruh temperatur air pendingin (ECT) terhadap putaran mesin (rpm) adalah berbanding terbalik, karena setiap kenaikan temperatur akan diikuti dengan penurunan putaran mesin (rpm). Pada saat temperatur air pendingin masih rendah dibutuhkan tercapainya temperatur kerja engine yang cepat (temperatur kerja air pendingin berkisar antara $80-90^{\circ} \mathrm{C}$ ). Untuk itu ECU akan mengatur putaran mesin tinggi sehingga akan meningkatkan jumlah siklus pembakaran persatuan waktu. Dengan demikian waktu pemanasan engine lebih cepat tercapai. Dengan menggunakan metode regresi linear Penurunan putaran mesin (rpm) terjadi pada setiap kenaikan temperatur air pendingin. Pada beban $\mathrm{AC}$ berkisar antara 5,510 s.d. $1,008 \times 10^{1}$ beban power steering pada kisaran antara 8,780 s.d. $1,192 \times 10^{1}$ pada beban electrical load pada kisaran antara 1,007 s.d. 1,280x $10^{1}$ dan tanpa beban pada kisaran antara 9,238 s.d. $1,215 \times 10^{1}$.

\section{Hubungan ECT terhadap sudut pengapian $\left(^{\circ}\right)$}

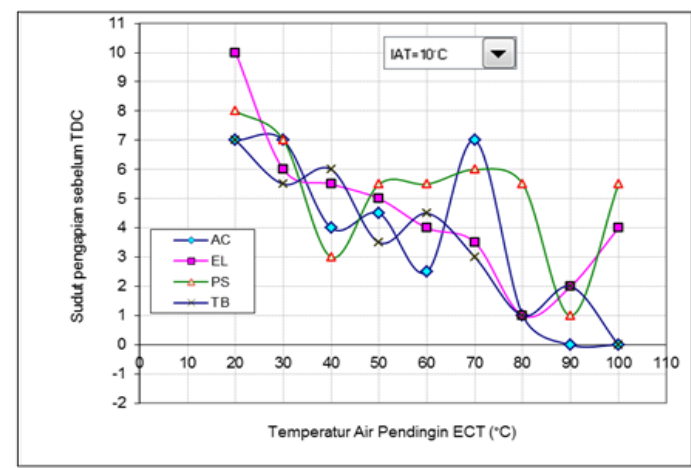

Gambar 28. Grafik hubungan antara ECT dengan sudut pengapian pada temperatur $10^{\circ} \mathrm{C}$

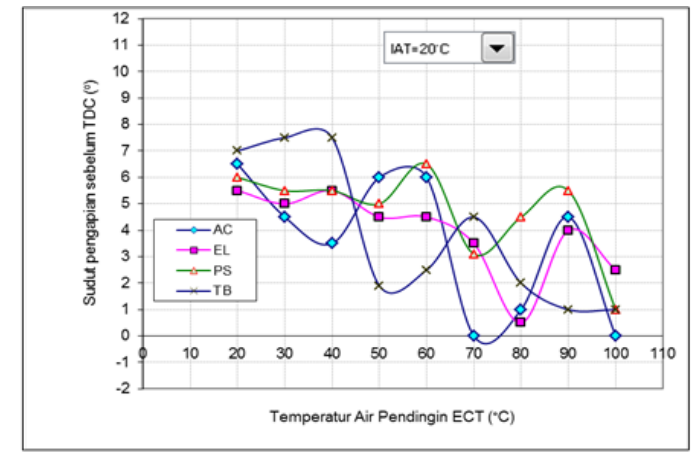

Gambar 29. Grafik hubungan antara ECT dengan sudut pengapian pada temperatur $20^{\circ} \mathrm{C}$ 


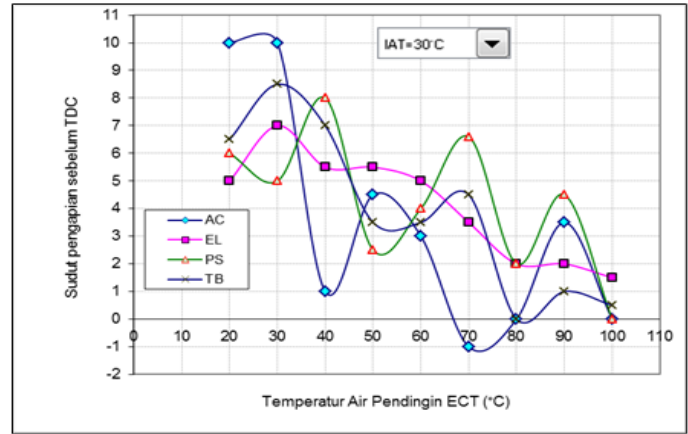

Gambar 30. Grafik hubungan antara ECT dengan sudut pengapian pada temperatur $30^{\circ} \mathrm{C}$

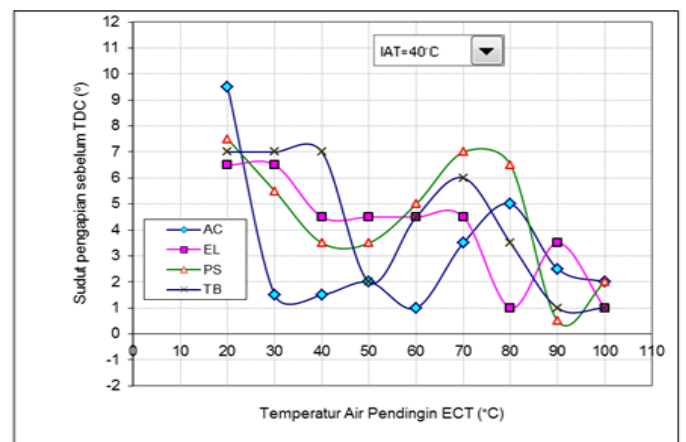

Gambar 31. Grafik hubungan antara ECT dengan sudut pengapian pada temperatur $40^{\circ} \mathrm{C}$

Dari gambar grafik 27,28,29 dan 30 dapat disimpulkan pengaruh temperatur air pendingin (ECT) terhadap sudut pengapian $\left(^{\circ}\right)$ adalah berbanding terbalik, Karena kenaikan temperatur air pendingin akan diikuti dengan penurunan sudut pengapian $\left({ }^{\circ} \mathrm{BTDC}\right)$. Engine yang telah menggunakan EMS besarnya kecepatan putaran engine (rpm) pada saat idle lebih di dominasi pada waktu pengapian. Semakin besar derajat pengapian ( $\left.{ }^{\circ} \mathrm{BTDC}\right)$ akan menghasilkan putaran mesin yang tinggi. Begitu juga sebaliknya semakin kecil sudut pengapian $\left({ }^{\circ}\right.$ BTDC) akan menghasilkan putaran mesin yang rendah. Penurunan sudut pengapian setiap kenaikan temperatur air pendingin pada beban AC berkisar antara 3,038 x 10 s.d $1,113 \times 10^{1}$ pada beban power steering berkisar antara $3,750 \times 10^{2}$ s.d 5,567 x $10^{2}$, pada beban electrical load berkisar antara $4,333 \times 10^{2}$ s.d $7,750 \times 10^{2}$ dan tanpa beban berkisar antara $5,500 \times 10^{2}$ s.d $9,917 \times 10^{2}$.

\section{Hubungan ECT terhadap konsumsi bensin}

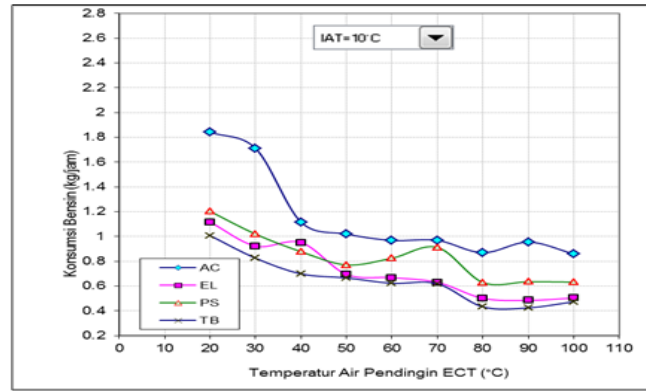

Gambar 32. Grafik hubungan antara ECT dengan konsumsi bensin pada temperatur $10^{\circ} \mathrm{C}$

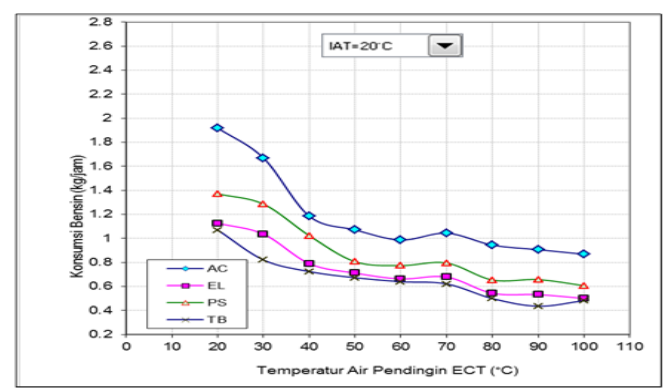

Gambar 33. Grafik hubungan antara ECT dengan konsumsi bensin pada temperatur $20^{\circ} \mathrm{C}$

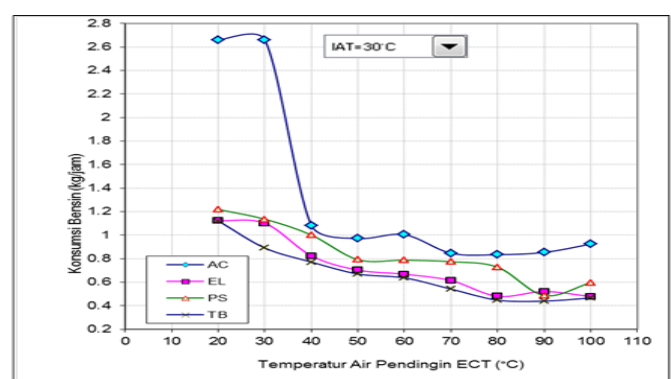

Gambar 34. Grafik hubungan antara ECT dengan konsumsi bensin pada temperatur $30^{\circ} \mathrm{C}$

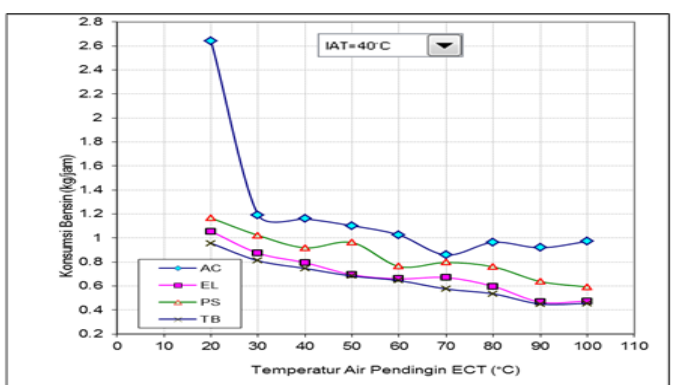

Gambar 35. Grafik hubungan antara ECT dengan konsumsi bensin pada temperatur $40^{\circ} \mathrm{C}$

Dari gambar grafik 32, 33, 34, dan 35 dapat disimpulkan pengaruh temperatur air pendingin (ECT) terhadap konsumsi bensin adalah berbanding terbalik, karena setiap kenaikan temperatur air pendingin akan menurunkan konsumsi bensin. Banyaknya konsumsi bensin pada engine 
dipengaruhi oleh 2 hal yaitu massa bensin (kg) yang diinjeksikan dan banyaknya penyemprotan injektor per satuan waktu. Penurunan konsumsi bensin setiap kenaikan temperatur air pendingin pada beban AC berkisar antara $1,123 \times 10^{-2}$ s.d $2,164 \times 10^{-2} \mathrm{~kg} / \mathrm{jam}$, pada beban power steering berkisar antara $6,311 \times 10^{-3} \mathrm{s.d}$ $9,482 \times 10^{-3} \mathrm{~kg} / \mathrm{jam}$, pada beban electrical load berkisara antara $6,608 \times 10^{-3} \mathrm{s.d} \mathrm{7,876}$ $\mathrm{x} 10^{-3} \mathrm{~kg} / \mathrm{jam}$ dan tanpa beban berkisar antara $6,024 \times 10^{-3}$ s.d $7,920 \times 10^{-3}$ $\mathrm{kg} / \mathrm{jam}$.

\section{Kesimpulan}

Massa bensin terbesar terjadi pada temperatur air pendingin $20^{\circ} \mathrm{C}-30^{\circ} \mathrm{C}$ pada seluruh beban ISC, massa bensin terbesar terjadi pada beban $\mathrm{AC}$, ECT $20^{\circ} \mathrm{C}$ dan IAT $30^{\circ} \mathrm{C}$ dengan nilai $1.259 \times 10^{-5} \mathrm{~kg}$. Semakin tinggi temperatur air pendingin maka akan menaikan nilai massa udara. Massa udara terbesar terjadi pada beban $\mathrm{AC}, \mathrm{ECT} 90^{\circ} \mathrm{C}$ dan IAT $40^{\circ} \mathrm{C}$ dengan nilai $1.138 \times 10^{-4} \mathrm{~kg}$. Semakin tinggi temperatur air pendingin maka akan menaikan nilai Air Fuel Ratio (AFR). AFR terendah terjadi pada beban AC, ECT $20^{\circ} \mathrm{C}$ dan IAT $30^{\circ} \mathrm{C}$ dengan nilai 6,270:1. Semakin tinggi temperatur air pendingin maka putaran mesin (rpm) akan turun. Putaran mesin tertinggi terjadi pada beban $\mathrm{AC}$, ECT $20^{\circ} \mathrm{C}$ dan IAT $30^{\circ} \mathrm{C}$ dengan nilai $1760 \mathrm{rpm}$. Semakin tinggi temperatur air pendingin akan menurunkan sudut pengapian (BTDC). Sudut pengapian tertinggi terjadi pada beban $\mathrm{AC}, \mathrm{ECT} 20^{\circ} \mathrm{C}$ dan IAT $30^{\circ} \mathrm{C}$ dengan nilai $10^{\circ}$ sebelum TDC. Semakin tinggi temperatur air pendingin akan menurunkan konsumsi penggunaan bensin. Konsumsi bensin terbesar terjadi pada beban $\mathrm{AC}, \mathrm{ECT} 20^{\circ} \mathrm{C}$ dan IAT $30^{\circ} \mathrm{C}$ dengan nilai $2,660 \mathrm{~kg} / \mathrm{jam}$.

\section{Referensi}

[1] E karyanto, Pedoman reparasi motor bensin, Radar jaya offset, Jakarta , 1994.
[2] M Sutarman, Ohan juhana, Service dan reparasi auto mobil, Pustaka grafika,Bandung , 2001.

[3] Daryanto, Prinsip dasar Mesin Otomotif, Alfabeta, Bandung, 2011.

[4] Supplement pedoman reparasi Toyota Avanza

[5] Modul Engine Control System. VEDC, Malang.

[6] Toyota Step 1, Toyota training centre.

[7] Joko Saraswo, Aris. Belajar Sistem Aliran Bahan Bakar Pada Mesin EFI. Raswo.

[8] Joko Saraswo, Aris. Sistem Pengapian elektronik. Raswo Publisher, Solo. 2010

[9] Manual Shop Toyota Avanza, Xenia, Toyota corp, 2006.

[10] Tugas Akhir, Darmadi. Perbandingan unjuk kerja motor bensin Toyota $4 \mathrm{k}$ menggunakan camshaft modifikasi, Malang, 1998. 